Qawwãm • Volume 13 Nomor 1, Juni 2019

\title{
FAKTOR EKONOMI DALAM PERNIKAHAN DINI PADA MASYARAKAT SASAK LOMBOK
}

\author{
Siti Nurul Khaerani ${ }^{1}$ \\ Khaeranis@Yahoo.com
}

\begin{abstract}
ABSTRAK: Pernikahan dini merupakan merupakan pernikahan yang terjadi pada usia yang masih belum cukup dewasa. Di Lombok pernikahan dini masih cukup tinggi terjadi. Terkait dengan fenomena pernikahan di bawah umur yang terjadi di masyarakat Nusa Tenggara Barat, Gubernur NTB mengeluarkan kebijakan melalui surat edaran gubernur NTB tentang pendewasaan usia perkawinan yang bertujuan untuk meminimalisir para pelaku nikah dini khususnya di wilayah Provinsi Nusa Tenggara Barat. Penelitian ini menggunakan metodologi kualitatif. Informan yaitu pelaku dan keluarga. Kondisi pelaku pernikahan dini pada saat melangsungkan pernikahan rata-rata putus sekolah mulai dari kelas 2 SMP, dengan rata-rata pelaku pernikahan usia dini berusia sekitar 15-19 tahun. Faktor ekonomi merupakan salah satu penyebab terjadinya pernikahan dini, yaitu tidak ada biaya untuk melanjutkan sekolah menyebabkan mereka berfikir lebih baik menikah dari pada menganggur. Selain itu terdapat juga karena adanya faktor sosial atau lingkungan dan pendidikan. Pernikahan dini memberikan dampak baik dari segi kesehatan, pendidikan dan kemiskinan.
\end{abstract}

Keyword: Pernikahan dini,ekonomi, sosial atau lingkungan, pendidikan

\section{Pendahuluan}

Permasalahan-permasalahan dalam keluarga banyak yang diawali dari kurang matangnya seseorang ketika melangsungkan pernikahan, baik kematangan secara fisik maupun secara psikis. Kematangan secara fisik dan psikis diukur dari umur seseorang. Mereka yang melangsungkan pernikahan- pernikahan yang tidak memenuhi standar tersebut sangat rentan memunculkan persoalan-persoalan baru dalam keluarga. Oleh karenanya perkawinan dini menjadi isu yang menarik bagi banyak pihak baik di tingkat nasional maupun didaerah. Masing-masing daerah berusaha menekan persoalan-persoalan tersebut agar tidak muncul.

Pernikahan dini merupakan pernikahan yang dilangsungkan saat remaja, belum atau baru saja berakhir. Menurut WHO, batas usia remaja adalah 12-24 tahun. Departemen Kesehatan membatasi usia remaja pada rentang usia sekitar 10-19 tahun, Sedangkan menurut Direktorat Remaja dan Perlindungan Hak Reproduksi BKKBN, usia remaja dengan batasan umur 10-21 tahun. ${ }^{2}$ Definisi lain tentang pernikahan dini adalah sebuah bentuk ikatan atau pernikahan yang salah satu atau kedua pasangan berusia di bawah umur 18 tahun atau sedang mengikuti pendidikan di Sekolah Menengah Atas. Jadi sebuah pernikahan disebut pernikahan dini, jika kedua atau salah satu pasangan masih berusia di bawah umur 18 tahun. Perkawinan memungkinkan perempuan Indonesia untuk menikah dini pada usia 18 tahun, namun kenyataannya pada usia lebih dini dimungkinkan dengan izin pengadilan. ${ }^{3}$ Pernikahan dini selain

\footnotetext{
${ }^{1}$ Penulis merupakan dosen pada Fakultas Ekonomi dan Bisnis Islam

${ }^{2}$ Muhyi, J. a.,Jangan Sembarang Menikah Dini. (Depok: PT. Lingkar Pena Kreativa.2006), 12.

3 Sulistiyowati Irianto, Perempuan dan Hukum Menuju Hukum Yang Berpersepektif Kesetaraan dan Keadilan. (Jakarta: Yayasan Obor Indonesia. 2006), 284.
} 
menimbulkan persoalan pada masalah kehidupan keluarga kelak juga sangat berpengaruh pada kesehatan fisik perempuan itu sendiri. Akibat dari terjadinya pernikahan pada usia dini lebih tampak nyata pada remaja putri dibandingkan remaja laki-laki. Seperti terjadinya abortus atau keguguran, karena memang secara fisiologis organ reproduksi seperti rahim remaja belum cukup sempurna.

Di beberapa daerah, dominasi orang tua biasanya masih kuat dalam menentukan perkawinan anak dalam hal ini remaja perempuan. Alasan terjadinya pernikahan dini adalah pergaulan bebas seperti hamil di luar pernikahan dan alasan ekonomi. Perempuan muda yang melakukan pernikahan dini sering dipaksa keluar dari sekolah tanpa pendidikan atau putus sekolah, status sosial yang lebih rendah di keluarga, suami kurang memiliki kontrol reproduksi akibatnya kesehatan perempuan muda yang melakukan pernikahan dini terpengaruh karena tubuh terlalu muda hamil dan melahirkan, sehingga risiko kematian ibu dapat terjadi baik pada masa hamil, melahirkan dan nifas. Penting untuk diketahui bahwa kehamilan pada usia kurang dari 17 tahun meningkatkan risiko komplikasi medis, baik pada ibu maupun pada anak. Kehamilan di usia yang sangat muda ini ternyata berkorelasi dengan angka kematian dan kesakitan ibu. Disebutkan bahwa anak perempuan berusia 10-14 tahun berisiko lima kali lipat meninggal saat hamil maupun bersalin dibandingkan kelompok usia 2024 tahun, sementara risiko ini meningkat dua kali lipat pada kelompok usia 15-19 tahun. 4

Hasil penelitian dari Wulandari dan Sarwititi Sarwoprasodjo memperkuat bahwa status ekonomi keluarga terbukti memiliki pengaruh signifikan terhadap motif menikah dini dan menunjukkan bahwa setiap kenaikan status ekonomi keluarga akan menurunkan rata-rata motif menikah dini. Hasil analisis tersebut sejalan dengan data yang diperoleh di lapangan, yakni sekitar 80 persen responden berasal dari keluarga dengan status ekonomi menengah ke bawah dengan pengeluaran keluarga rata-rata sekitar kurang dari Rp1.360.000 perbulan. Status ekonomi tersebut sebenarnya berkaitan dengan tingkat pendidikan remaja dimana sekitar 66.6 persen responden hanya berpendidikan hingga SLTP saja, itu pun tidak seluruh responden berstatus tamat SLTP. Sekitar 23.3 persen responden hanya menempuh pendidikan hingga kelas dua SLTP saja. Hal tersebut disebabkan oleh ketidakmampuan orangtua dalam membiayai pendidikan responden, sehingga responden secara terpaksa putus sekolah dan lebih memilih menikah untuk menghindari hal-hal yang tidak diharapkan . Hal ini sejalan dengan norma yang berkembang di lapangan bahwa terdapat nilai yang berkembang bahwa anak perempuan merupakan aset ekonomi keluarga, dimana anak perempuan diharapkan dapat mengangkat derajat ekonomi keluarga. Salah satu diantaranya adalah dengan menikah diusia dini. ${ }^{5}$ Penelitian yang dilakukan oleh Budi Setyawati dkk juga menghasilkan bahwa secara umum hampir separuh wanita yang menikah dini berlatar belakang status ekonomi rendah. Jika di telaah lebih lanjut terlihat pula bahwa pada wanita yang menikah dini (menikah $<20$ tahun) saat berusia $<30$ tahun, usia 30-50 tahun hingga $>50$ tahun saat ditemui sebagian besar masih

4 Ibid...40 - 41 .

5 Wulandari dan Sarwititi Sarwoprasodjo, "Pengaruh Status Ekonomi Keluarga Terhadap Motif Menikah Dini di Perdesaan”, Sodality : Jurnal Sosiologi Pedesaan | April (2014), hlm : 58. 


\section{Qawwãm • Volume 13 Nomor 1, Juni 2019}

dalam status keluarga ekonomi rendah. ${ }^{6}$

Di NTB sendiri pernikahan di bawah umur, atau disebut dengan pernikahan dini, dikategorikan masih tinggi bila dibanding dengan daerah-daerah lain di Indonesia. Menurut makrifudin, Tahun 2016 tercatat sekitar 51 persen pernikahan dini terjadi di wilayah NTB. angka pernikahan usia dini di NTB cukup tinggi se Indonesia, bahkan NTB nomor dua setelah Jawa Barat. ${ }^{7}$ Terkait dengan fenomena pernikahan di bawah umur yang terjadi di masyarakat Nusa Tenggara Barat, Gubernur NTB mengeluarkan kebijakan melalui surat edaran gubernur NTB Nomor: 180/1153/Kum/2014 tentang pendewasaan usia perkawinan yang bertujuan untuk meminimalisir para pelaku nikah dini khususnya di wilayah Provinsi Nusa Tenggara Barat.

Terkait Surat Edaran Gubernur NTB tersebut, ada beberapa poin yang dimunculkan sekaligus sebagai kritikan terhadap Undang-Undang Perkawinan No.1/1974 pada pasal 7 ayat (1). Bahwa di dalam pasal 7 ayat (1) masih memberikan peluang kepada siapapun sebagai warga negara untuk melakukan perkawinan di bawah umur. Oleh karena itu, Pemprov Nusa Tenggara Barat melalui surat edaran yang telah diterbitkannya memberikan masukan terhadap pasal 7 ayat (1) mengatakan bahwa idealnya seseorang melakukan pernikahan baik laki-laki maupun perempuan pada usia 21 tahun.

Artikel ini membahas tentang faktor ekonomi terhadap terjadinya pernikahan dini di Lombok, dampak terjadinya pernikahan dini serta upaya-upaya yang akan dilakukan untuk menekan pernikahan dini tersebut. Metode yang digunakan dalam penelitian ini metodologi kualitatif, karena itu pengambilan datanya menggunakan wawancara, observasi dan dokumentasi.

\section{Faktor-Faktor Penyebab Terjadinya Pernikahan Dini}

Ada beberapa faktor yang menyebabkan terjadinya pernikahan dini pada masyarakat di Pulau Lombok, termasuk faktor ekonomi. Wawancara dibagi berdasarkan jenis informan yaitu pelaku dan keluarga. Kondisi pelaku pernikahan dini pada saat melangsungkan pernikahan rata-rata putus sekolah mulai dari kelas 2 SMP, tidak melanjutkan sekolah ke tingkat SMA, putus sekolah pada kelas 1 SMA/MA, kelas 2 SMA, dan kelas 3 SMA (pada saat ujian). Dengan rata-rata pelaku pernikahan usia dini berusia sekitar 15-19 tahun.

Sebagian besar orang tua dari pelaku pernikahan dini tidak mengetahui rencana pernikahan mereka dan pada dasarnya tidak menyetujui, pernikahan terjadi melalui proses merarik (kawin lari), yang pada akhirnya mau tidak mau dinikahkan. Ada beberapa orang tua yang mengetahui rencana pernikahan, karena anak tidak sekolah lagi hanya tamat SMP, disebabkan karena faktor ekonomi yaitu tidak ada biaya untuk melanjutkan sekolah menyebabkan mereka berfikir lebih baik menikah dari pada menganggur.

${ }^{6}$ Profil Sosial Ekonomi, Paritas, Status Dan Perilaku Kesehatan Pada Wanita Yang Menikah Dini Di Indonesia”, Jurnal Kesehatan Reproduksi Vol. 4 No 2, Agustus (2013), hlm:51-60

${ }^{7}$ Disampaikan Lalu Makrifuddin, pada Rapat Koodinasi Daerah (Rakorda) BKKBN se NTB. Rapat ini berlangsung di Wisma Sumbawa, Lombok Pos.net, 23 Mei 2016. 
Adapun faktor penyebabab terjadinya pernikahan usia dini yaitu sebagai berikut: 1. Sosial:

Faktor sosial dalam hal ini adalah pengaruh lingkungan yaitu pengaruh pergaulan, seperti misalnya lingkungan banyak yang tidak sekolah dan juga teman sepergaulan yang banyak yang menikah dini. Seperti kita ketahui bahwa lingkungan mempunyai peranan yang penting dalam perkembangan individu, dan secara teori hal ini ini pada umumnya menunjukkan kebenarannya. Dalam lingkungan sosial atau lingkungan masyarakat terjadi adanya interaksi individu satu dengan individu lain. Sehingga keadaan masyarakatpun akan memberikan pengaruh tertentu terhadap perkembangan individu. Bagaimanapun juga hubungan antara individu dengan lingkungannya terdapat hubungan yang saling timbal balik. Dimana lingkungan dapat mempengaruhi individu, dan sebaliknya individu juga dapat mempengaruhi lingkungan. Dalam kasus pernikahan dini pada masyarakat di Lombok khususnya remaja, lingkungan pergaulan sangat mempengaruhi seperti yang disampaikan oleh beberapa informan perempuan bahwa mereka menikah karena pengaruh pergaulan. Menurut para pelaku pernikahan dini faktor-faktor penyebab terjadinya pernikahan dini antara lain pengaruh lingkungan. Mereka menikah karena keinginan sendiri dan disebabkan lingkungan. Seperti temen-temen bermain yang sebaya dengan mereka beberapa diantaranya sudah menikah, sehingga ketika bertemu dengan orang yang menurut mereka bertanggung jawab dan siap menikah mereka memutuskan untuk juga menikah. Faktor lingkungan dan pergaulan lainnya bukan saja karena bergaul dengan sesama teman perempuan tapi juga dengan teman-teman cowok yang tidak sekolah. Pada malamnya yang cowok sering datang midang (ngapel) ke rumah mereka, dan mengajak menikah, dan atas dasar suka dan cinta kepada cowok tersebut akhirnya memutuskan untuk menikah. Dan sebagian remaja putri sebenarnya ada faktor iri melihat temen mereka yang pacaran atau yang menikah cepat-cepat, perasaan seperti itu yang membuat remaja putri tidak berpikir panjang ketika memutuskan menikah.

Para pelaku pernikahan dini dari laki-laki juga mengatakan bahwa faktor penyebab terjadinya pernikahan dini yang disebabkan lingkungan antara lain pergaulan dengan teman-teman cowok yang tidak sekolah, kemudian diajak midang akhirnya ketemu jodoh memutuskan menikah. Walaupun sebenarnya ada informan tidak pernah berencana mau menikah lebih awal, pergaulanlah yang membuat mereka harus segera menikah karena dorongan dari teman yang menikah lebih dahulu.

Sikap individu terhadap lingkungan secara teoritis ada yang menolak atau menentang lingkungan. Dalam keadaan ini lingkungan dianggap tidak sesuai dengan yang ada dalam diri individu. Dalam keadaan yang tidak sesuai ini individu dapat memberikan bentuk atau perubahan lingkungan seperti yang dikehendaki oleh individu yang bersangkutan. Misalnya, walaupun lingkungan sekitar banyak yang tidak sekolah dan menikah dini, seorang individu dapat menolak dan tidak menerima begitu saja pengaruh lingkungan atau mengatasi pengaruh lingkungan yang ada di sekitarnya. Artinya orang dapat berusaha untuk dapat mengubah lingkungan yang tidak baik itu menjadi norma yang baik. Jadi individu secara aktif memberikan pengaruh terhadap lingkungannya. Akan tetapi ada individu yang menerima lingkungan. Dalam hal ini 


\section{Qawwãm • Volume 13 Nomor 1, Juni 2019}

keadaan lingkungan sesuai atau sejalan dengan yang ada dalam diri individu. Dengan demikian individu akan menerima lingkungan itu. Seperti yang terjadi pada pelaku pernikahan dini yang tidak mampu menolak lingkungan sekitar. Pada akhirnya ikut terlibat atau terpengaruh dengan keadaan sekitar. ${ }^{8}$

\section{Pendidikan}

Faktor berikutnya yang menjadi penyebab terjadinya pernikahan usia dini adalah karena pendidikan. Dalam hal ini para pelaku pernikahan dini menikah karena putus sekolah, sehingga karena tidak ada kerjaan dan tidak ada kesibukan menyebabkan mereka memilih menikah. Selain itu ada beberapa informan juga mengatakan bahwa orang tua kurang memberikan pandangan untuk sekolah. Hal ini banyak terjadi terutama jika orang tua juga berpendidikan rendah dan dengan ekonomi yang kurang. Alternatif menikah menjadi pilihan bagi anak-anak yang menganggur yang tidak bekerja, dan tidak sekolah. Sehingga rendahnya tingkat pendidikan ataupun pengetahuan orang tua, anak dan masyarakat mempengaruhi pola pikir mereka dalam memahami dan mengerti makna dari tujuan dilangsungkannya pernikahan. Hal ini yang menyebabkan adanya kecendrungan menikahkan anaknya yang masih di bawah umur.

Kasus pernikahan dini di pulau Lombok masih cukup tinggi salah satu Kabupaten yaitu Lombok Timur (Lotim) misalnya setiap tahun, angka pernikahan usia dini dipekirakan mencapai 7 ribu sampai 9 ribu kasus. Dan hal ini menyebabkan terjadinya sejumlah persoalan. Seperti yang diungkapkan oleh Kepala Badan Pemberdayaan Perempuan Keluarga Berencana (BPPKB) Lombok Timur, Suroto, dalam pertemuan advokasi kepala desa/lurah dalam pengawasan usia kelahiran dan kekerasan dalam rumah tangga Tingginya angka pernikahan dini katanya, disebabkan karena rendahnya pendidikan. Sebagian besar pelaku menikah usia dini, adalah mereka yang putus sekolah. Berdasarkan data, pernikahan usia dini berusia dibawah 19 tahun. Akibat masalah ini, kini angka kelahiran di Lotim terus mengalami peningkatan. Bahkan dalam setahun angka kelahiran mencapai 26 ribu dari total pendudukan Lotim mencapai satu juta lebih. "Pertumbuhan penduduk lebih cepat dari pertumbuhan ketersedian pangan". Pernikahan usia dini lanjutnya, salah satu tantangan yang dihadapi Lotim saat ini. Pihaknya pun bersama pihak terkait lainnya terus melakukan upaya maksimal untuk menekan angka nikah usia dini. Jika ini tidak disikapi, maka anak yang akan menjadi korban. "Inilah yang menjadi penyebab kasus penelantaran anak tinggi. Karena banyak anak yang tidak terpenuhi kebutuhannya". 9

\section{Ekonomi}

Faktor berikutnya adalah faktor ekonomi. Kondisi ekonomi yang rendah membuat pelaku pernikahan dini memutuskan untuk menikah. Tidak ada biaya sekolah menjadi alasan mereka untuk putus sekolah. Beberapa informan mengatakan bahwa menikah karena tidak sekolah sehingga tidak ada yang membuat sibuk. Beberapa informan mengatakan tidak sekolah disebabkan tidak ada biaya utuk

\footnotetext{
${ }^{8}$ Bimo Walgito, Pengantar Psikologi Umum, (Yogyakarta: Andi,1989), 55-56

${ }^{9}$ http:/ /www.radarlombok.co.id/kasus-pernikahan-dini-lotim-masih-tinggi.html, 28 Juli 2016.
} 
melanjutkan sekolah. Walaupun mereka sebenarnya juga ingin tetap sekolah tapi kondisi perekonomian orang tua yang sangat memprihatinkan, mereka tidak mampu untuk menyekolahkan anak-anaknya. Sehingga orang tua lebih senang jika mereka pergi bekerja membantu mereka di sawah dari pada bersekolah, dan dari pada hidup dengan kondisi bersekolah tidak, hidup senang juga tidak, akhirnya memutuskan untuk menikah. Selain karena tidak ada biaya sekolah, harapan akan terjadinya perubahan ekonomi yang lebih baik dengan menikah menjadi alasan terjadinya pernikahan dini. Ada beberapa informan memutuskan menikah karena faktor tidak ada kesibukan yang diakibatkan tidak melanjutkan sekolah karena tidak ada biaya sekolah, selain itu karena orang tuanya kurang memberikan pandangan untuk sekolah sehingga ia berharap dengan menikah dapat menyebabkan terjadinya perubahan ekonomi menjadi lebih baik dan ingin meningkatkan ekonomi mereka. Dengan menikah kondisi kehidupan diharapkan menjadi semakin baik.

Walaupun demikian ada juga ekonomi yang kurang diharapkan dapat meningkat dengan menikah dini atau dengan kata lain mereka berharap dengan menikah agar ekonomi berubah menjadi lebih baik. Pernikahan dini terjadi karena kondisi perekonomian dalam keluarga yang tergolong kurang atau dalam garis kemiskinan. Demi meringankan beban orang tua, anak perempuannya dinikahkan dengan laki-laki yang dianggap mampu. Orang tua menganggap jika anak gadisnya ada yang melamar dan mengajak menikah, setidaknya ia akan mandiri dan tidak lagi bergantung kepada orang tua, karena sudah ada suami yang siap menafkahi. Tetapi tidak jarang mereka menikah dengan status ekonomi yang tidak jauh berbeda, sehingga malah menimbulkan kemiskinan baru dan persoalan-persoalan baru.

Anak perempuan oleh sebagian orang tua dianggap asset, sehingga ketika ada yang melamar orang tua berharap dapat meringankan beban keluarga, bahkan mengangkat derajat keluarga. Apalagi dengan kondisi tradisi masyarakat Sasak Lombok dalam proses pernikahan dimana terjadi tawar menawar pemberian uang ke pihak perempuan oleh pihak laki-laki. Hal ini sering dimanfaakan oleh keluarga untuk mendapatkan uang yang banyak dari pihak keluarga laki-laki, karena jika tidak maka keluarga perempuan tidak akan memberikan hak wali mereka untuk menikahkan anak perempuannya.

Dan jika di lihat dari analisis gender yang berkaitan dengan "pernikahan usia dini" Yaitu: Analisis "longway" dimana analisis ini digunakan untuk menganalisis issue yang teriadi di masyarakat yang berhubungan dengan pemberdayaan perempuan dengan kriteria pertama kesejahteraan, dimana anak remaja perempuan di dalam keluarga dalam pemenuhan status gizinya yaitu kecukupan pangan dan tingkat pendidikan masih dinomor duakan dari anak laki-laki. Kedua yaitu akses, lebih rendahnya anak remaja perempuan memperoleh akses terhadap sumber daya menyebabkan produktifitas remaja perempuan cenderung lebih rendah dari laki-laki. Ketiga terkait kesadaran, masih rendahnya informasi yang diperoleh anak remaja perempuan mengenai kesehatan dan kematangan alat reproduksinya seteleh mereka mengalami menstruasi. Keempat, partisipasi yaitu peran serta orang tua dalam memberikan pendidikan seks pengawasan prilaku anak perempuan masih rendah. Karena orang tua masih menganggap tabu dalam memberikan informasi dan edukasi tentang seksualitas dan perilaku. Dan kelima, kontrol yaitu peran ayah dalam 


\section{Qawwãm • Volume 13 Nomor 1, Juni 2019}

pengambilan keputusan terhadap kasus memaksakan anak perempuannya untuk cepat menikah cukup besar. Hal ini juga dipengaruhi oleh faktor sosial budaya yang mengajarkan bahwa anak yang tidak patuh akan kualat. ${ }^{10}$

\section{Dampak Melangsungkan Perkawinan Pada Usia Dini}

Pada dasarnya para pelaku pernikahan dini baik laki-laki dan perempuan tidak memahami sepenuhnya dampak dari adanya pernikahan dini. Karena memang tidak mempersiapkan diri untuk menikah. Pernikahan dini terjadi karena memang mereka menikah untuk meningkatkan ekonomi selain faktor lingkungan dan dipengaruhi oleh temannya yang banyak menikah di usia muda.

Dari uraian beberapa informan bahwa dampak dari adanya pernikahan dini adalah sebagai berikut:

1. Putus sekolah,

Pada beberapa kasus, informan pelaku pernikahan dini ingin melanjutkan sekolah, akan tetapi terhambat peraturan yang tidak mengizinkan anak melanjutkan sekolah apabila telah menikah. Hal ini tentu saja mengakibatkan remaja yang menikah dini menjadi kehilangan kesempatan untuk menutut ilmu sebagai bekal untuk hidup di masa depan. Sebagian besar para informan menyadari bahwa dengan menikah maka mereka tidak akan bisa melanjutkan sekolah. Kesadaran akan pentingnya pendidikan menjadi terabaikan karena keinginan atau keterpaksaan untuk menikah.

2. Masa depan tidak bagus dan kurang mampu mengurus keluarga.

Sebagian informan pelaku pernikahan dini hanya menyadari sesaat saja, bahwa dampak mereka menikah usia dini adalah dimarahi orang tua. Sebagiannya menyadai bahwa dengan menikah dini maka masa depan mereka tidak bagus. Sebagaimana diketahui bahwa perkawinan pada umumnya merupakan suatu masa peralihan dalam kehidupan seseorang dan oleh karenanya terkadang membuat orang strees. Untuk itu menghadapi perkawinan diperlukan kesiapan mental setiap pasangan dari suami maupun istri. Setiap pasangan menyadari bahwa ia mulai beralih dari masa hidup sendiri ke masa hidup bersama dan berkeluarga. Kesiapan dan kematangan mental ini biasanya belum dicapai pada umur di bawah 20 tahun. Sehingga dikhawatirkan, keputusan yang diambil untuk menikah adalah keputusan remaja yang jiwa dan kondisi psikologisnya belum stabil. Keputusan pasangan yang bukan dewasa, umumnya belum menyadari bahwa menikah adalah suatu keputusan besar dimana akan menimbulkan hak dan kewajiban dalam perkawinan yang dijalaninya. Bila mereka kurang dapat menyesuaikan diri maka akan timbul berbagai masalah dalam hubungan keluarga dan masyarakat. Akan tetapi jika menikah dengan kondisi emosional dan berpikir yang matang, para pelaku nikah usia ideal selalu cerdas dalam menyelesaikan berbagai masalah di dalam rumah tangganya.

Selain itu pernikahan dini memberikan pengaruh bagi kesejahteraan keluarga dan dalam masyarakat secara keseluruhan. Perempuan yang kurang berpendidikan dan tidak siap menjalankan perannya sebagai ibu akan kurang mampu untuk mendidik

${ }^{10}$ Eva Eliya Sibagariang, Kesehatan Reproduksi Wanita, Edisi Revisi, (Jakarta: Trans Info Media. 2016), 43-45. 
anaknya, sehingga anak akan tumbuh dan berkembang secara kurang baik, yang dapat merugikan masa depan anak tersebut. Akan tetapi sebaliknya orang tua yang menikah di usia ideal mampu mendidik anak mereka dengan sebaik mungkin. Dengan kematangan yang dimilikinya, orang tua yang menikah di usia ideal mampu membimbing anak mereka untuk menjadi anak cerdas yang sesuai dengan kebutuhan dunia pendidikan. Orang tua juga memiliki tanggung jawab yang lebih besar dalam mencukupi kebutuhan pendidikan anak. Kondisi rahim yang matang bagi wanita di usia ideal, memiliki peluang besar untuk menghasilkan bibit-bibit unggul yang sesuai dengan harapan. Kedua calon mempelai yang memiliki usia ideal sudah tentu memiliki pandangan yang luas tentang bagaimana peran yang sesungguhnya antara laki-laki dan perempuan. Dan hal ini dapat meminimalkan perceraian. Karena tidak jarang pasangan ini mengalami ketidakharmonisan dalam kehidupan keluarga, sehingga pernikahan tidak bahagia, bahkan dapat berakhir dengan perceraian. Dalam hal ini maka remaja wanita lebih menderita dari remaja pria.

3. Kesehatan

Sebagian besar informan tidak mengetahui dampak buruk terhadap kesehatan akibat pernikahan dini. Secara biologis alat reproduksinya belum matang (masih dalam proses menuju kematangan) sehingga belum siap untuk melakukan hubungan seks dengan lawan jenisnya. Secara medis menikah di usia dini dapat mengubah sel normal (sel yang biasa tumbuh pada anak-anak) meniadi sel ganas yang akhirnya dapat menyebab infeksi kandungan dan kanker. Selain itu resiko kesehatan terjadi pada pasangan wanita pada saat mengalami kehamilan dan persalinan. Kehamilan mempunyai dampak negatif terhadap kesejahteraan seorang remaja. Sebenarnya ia belum siap mental untuk hamil, namun karena keadaan, ia terpaksa menerima dengan risiko. Berikut beberapa resiko kehamilan dan persalinan yang dapat dialami oleh remaja (usia kurang dari 20 tahun): Kurang darah (anemi) ada masa kehamilan dengan akibat yang buruk bagi janin yang dikandungnya seeperti pertumbuhan janin terhambat, kelahiran prematur, kurang gizi pada masa kehamilan yang dapat mengakibatkan perkembangan biologis dan kecerdasan janin terhambat. Bayi lahir dengan berat badan rendah. Penyulit pada saat melahirkan seperti pendarahan dan persalinan lama. Preeklampsi dan eklampsi yang dapat membawa maut bagi ibu maupun bayinya. Ketidakseimbangan besar bayi dengan lebar panggul. Biasanya ini akan menyebabkan macetnya persalinan. Bila tidak diakhiri dengan operasi Caesar maka keadaan ini akan menyebabkan kematian ibu maupun janinnya. Pasangan yang kurang siap untuk menerima kehamilan cenderung untuk mencoba melakukan pengguguran kandungan (aborsi) yang dapat berakibat kematian bagi wanita. Pada wanita yang menikah sebelum usia 20 tahun mempunyai risiko kira-kira dua kali lipat untuk mendapatkan kanker serviks dibandingkan dengan wanita yang menikah pada umur yang lebih tua. ${ }^{11}$

${ }^{11}$ Eva Eliya Sibagariang, Kesehatan Reproduksi .... Hal.67. 


\section{Qawwãm • Volume 13 Nomor 1, Juni 2019}

Dari hasil wawancara dengan beberapa informan yang menikah dini, sebagian dari mereka tidak mengetahui masalah yang ditimbulkan dengan adanya pernikahan dini. Bagi mereka dampak yang ada hanyalah putus sekolah dan dimarahi oleh orang tua mereka. Pengetahuan mereka tentang kesehatan reproduksi sangatlah minim, sehingga resiko-resiko yang dihadapi jika menikah di bawah umur tidak menjadi pertimbangan bagi mereka.

\section{Kemiskinan}

Beberapa orang tua informan berharap dengan menikahkan anak perempuan sebagai solusi untuk mengurangi beban ekonomi keluarga, karena kebutuhan hidup sehari-hari seperti kebutuhan pangan, sandang dan papan menjadi tanggung jawab suami. Akan tetapi hal tsb sering kali tidak terwujud, jika kondisi ekonomi antara pihak keluarga perempuan dan laki-laki dalam status yang sama. Justru yang terjadi kondisi ekonomi bukan lebih baik, bahkan menjadi lebih buruk. Karena bertambahnya jumlah keluarga yang ada membuat tekanan ekonomi yang semakin besar pada rumah tangga dan dengan sumber penghasilan yang rendah bahkan tidak ada membuat mereka tetap mengalami kesulitan dalam memenuhi kehidupan sehari hari. Hal ini menyebabkan munculnya lingkaran kemiskinan yang baru pada keluarga tersebut. Apalagi tidak ada kesiapan dari segi ekonomi.

\section{Upaya-Upaya Yang Dilakukan Untuk Mengurangi Perkawinan Usia Dini}

Data di lapangan yang didapatkan dari para informan mengatakan bahwa beberapa orang tua berusaha untuk mencegah terjadinya pernikahan dini, orang tua sebenarnya sangat kecewa karena anaknya menikah ketika masih sekolah. Dan beberapa orang tua informan sudah berusaha mencegah berusaha keras mencegah agar pernikahan ditunda dulu sampai bisa ikut Ujian Nasional, tapi keluarga yang laki tetap ingin melanjutkannya bahkan pihak laki-laki keberatan kalau keluarga perempuan mengagalkan pernikahannya. Aparat desa sendiri tidak mencegah, bahkan pak RT dan kadus yang membantu prosesnya. Tidak ada sosialisasi dari aparat desa dan tokoh masyarakat tentang pernikahan dini, pengetahuan tentang pernikahan dini hanya mendengar dari ceramah tuan guru agar orang tua menjaga anak-anaknya untuk tidak nikah di bawah umur.

Pada beberapa daerah di Lombok seperti Lombok Tengah tepatnya di daerah Rembitan, tokoh masyarakat dan Kadus berembuk (ketemu) untuk mencegah terjadinya pernikahan dini. Selain itu di daerah Rembitan juga tidak dijamin oleh aparat desa untuk mempunyai buku nikah. Tidak ada sosialisasi khusus untuk mencegah terjadinya pernikahan dini secara langsung ke masyarakat, biasanya di digabung dengan kegiatan kesehatan dll. Dan juga belum ada koordinasi secara formal tokoh masyarakat, aparat desa, dan toga dengan KUA untuk mencegah terjadinya pernikahan dini.

Selain di Desa Rembitan Lombok Tengah, di beberapa tempat telah dilakukannya atau berusaha mencegah terjadinya pernikahan dini seperti di Desa Kekait dengan cara membuat awik-awik tentang pendewasaan usia perkawinan. Awiqawiq tersebut mengatur batas minimal untuk menikah, untuk perempuan minimal 
umur 19 (Sembilan belas) tahun, sementara laki-laki minimal berumur 21 (dua puluh satu) tahun. Bila ada yang nekat ingin menikah di luar umur tersebut, maka pasangan menikah akan dipisahkan. Kalau tidak bisa dipisahkan, maka akan kena denda Rp. 1,5 juta dan dilaporkan ke pihak berwajib.

Upaya untuk mencegah terjadinya pernikahan dini telah dilakukan oleh Kepala Kantor Urusan Agama antara lain melakukan; sosialisasi walaupuan masih bersifat insidentil, penyebabnya salah satunya faktor anggaran atau dana. Sosialisasi dilakukan oleh KUA ke majlis taklim, melalui nasihat perkawinan dan melalui khotbah nikah. Untuk koordinasi dengan kecamatan, kegiatan-kegiatan kepemudaan terkait dengan pernikahan dini juga masih bersifat insidentil. Sedangkan dengan pihak sekolah KUA tidak ada koordinasi kecuali di undang hal ini juga disebabkan tidak ada anggaran. Sebenarnnya kerjasama Kementrian Agama (Untuk Kota mataram) pernah ada dengan BKKBN. Pernah ada program Kursus untuk calon pengantin. Jika ada 10 orang mendaftar maka diarahkan untuk ke BKKBN kursus untuk calon pengantin tsb. Untuk pencegahan menikah di usia muda, jika KUA mengetahui maka KUA akan memangil kepala lingkungan, toga, toma tujuan kenapa mau menikah, jika tidak logis, maka dianjurkan melanjutkan sekolah. Pernah ada 6 pasang calon penganten di bawah umur hanya ada 2 (dua) yang bisa dicegah. Sedangkan kerjasama dengan dinas kesehatan, maka yang punya kewenangan adalah puskesmas. Baru ada MoU antara Kemenkes dan Kemenag terkait dengan pelayanan suntikan untuk calon pengantin.

Pada tingkat sekolah, salah satu kepala sekolah SMA I Keruak mengatakan bahwa mereka berusaha mencegah terjadinya pernikahan dini di kalangan siswa mereka, dengan cara sekolah bekerja sama dengan komite dengan memberi sanksi berupa denda kepada keluarga pelaku pernikahan dini dalam bentuk uang. Tetapi tetap saja pernikahan dini terjadi. Terutama menjelang Ujian Nasional.

Pemerintah Provinsi NTB sendiri melakukan berbagai macam upaya-upaya yang dilakukan oleh untuk kemudian meminimalisir tingginya angka perkawinan di bawah umur. Antara lain adanya surat edaran Nomor: 180/1153/Kum/2014 yang telah diterbitkan oleh Gubernur NTB. Surat edaran nomor 150/1138/Kum tentang pendewasaan usia perkawinan yang merekomendasikan usia perkawinan untuk lakilaki dan perempuan minimal 21 tahun. Surat edaran ini diterbitkan untuk mendorong seluruh satuan kerja perangkat daerah serta bupati/wali kota se-NTB melaksanakan program pendewasaan usia perkawinan sesuai dengan tugas dan tanggungjawab masing-masing.

\section{Simpulan}

Kesimpulan yang dapat diambil untuk menjawab rumusan masalah penelitian adalah sebagai berikut: terdapat beberapa faktor penyebab terjadinya pernikahan dini antara lain: faktor ekonomi dimana karena kondisi ekonomi yang memprihatinkan membuat pelaku pernikahan dini memutuskan untuk menikah. Selain itu juga terdapat faktor sosial atau faktor lingkungan dan faktor pendidikan. Dampak melangsungkan perkawinan pada usia dini, antara lain: Putus sekolah. Putus sekolah merupakan salah satu dampak terjadinya pernikahan dini walaupun pada beberapa kasus, informan pelaku pernikahan dini ingin melanjutkan sekolah, akan tetapi terhambat peraturan yang tidak mengizinkan anak melanjutkan sekolah apabila telah menikah; Berikutnya 


\section{Qawwãm • Volume 13 Nomor 1, Juni 2019}

adalah Masa depan tidak bagus dan kurang mampu mengurus keluarga. Dengan terjadinya pernikahan dini maka masa depanpun menjadi tidak menjanjikan, karena gagal dalam membangun cita-cita yang diharapkan oleh diri belaku dan keluarganya. Serta tidak mampu menyelesaikan urusan-urusan dalam keluarganya karena belum dewasanya cara berfikir dan bersikap. Berikutnya adalah dampak kesehatan walaupun sebagian besar informan tidak mengetahui dampak kesehatan akibat terjadinya pernikahan dini. Dan yang terakhir adalah kemiskinan, hal ini karena ketidaksiapan ekonomi menambah beban berat ekonomi dan memunculkan lingkaran kemiskinan baru dengan bertambahnya beban keluarga.

Terdapat beberapa Upaya-upaya yang dilakukan untuk mengurangi perkawinan Usia dini, antara lain: pada beberapa tokoh masyarakat dan kadus berembuk (ketemu) untuk mencegah terjadinya pernikahan dini, dengan bertemu beberapa kali dalam sebulan, kemudian tidak menjamin adanya buku nikah; Berikutnya di salah satu sekolah yaitu pihak sekolah bekerja sama dengan komite akan memberikan sanksi berupa denda dalam bentuk uang kepada pelaku pernikahan dini; Selain itu dibutuhkan koordinasi secara formal tokoh masyarakat, aparat desa, dan toga dengan KUA untuk mencegah terjadinya pernikahan dini; Diperlukan upaya sosialisasi secara khusus tentang dampak pernikahan dini terhadap kesehatan. Kantor urusan agama sendiri telah melaksanakan beberapa hal antara lain: Telah melaksanakan program sosialisasi ke majlis taklim, nasihat perkawinan, melalui khotbah nikah. Melakukan koordinasi dengan kecamatan, kegiatan-kegiatan kepemudaan terkait dengan pernikahan dini. Memperkuat kerjasama Kementrian Agama dengan kabupaten/kota dengan bekerjasama dengan BKKBN. Memsosialisasikan dan menerapkan surat edaran yang dikelurkan oleh Pemerintah provinsi NTB dengan Nomor: 180/1153/Kum/2014 yang telah diterbitkan oleh Gubernur NTB. Surat edaran nomor 150/1138/Kum tentang pendewasaan usia perkawinan yang merekomendasikan usia perkawinan untuk laki-laki dan perempuan minimal 21 tahun.

\section{Saran}

Diperlukan sosialisasi kepada masyarakat, terutama orangtua (pentingnya pendidikan keluarga), bahwa pernikahan dini akan merugikan anak baik laki-laki maupun perempuan karena menghambat perkembangan anak dalam bidang pendidikan/pola berfikir dan anak yang hamil di usia muda rentan terhadap masalah kesehatan dan kehamilan. Perlu ada gerakan secara masif dari semua pihak untuk mencegah pernikahan dini pada tingkat desa (dengan memasukkan dana sosialisasi di dana desa). Pada tingkat sekolah perlu ada program terkait dampak pernikahan dini. Perlu ada koordinasi yang lebih intensif baik antara tokoh agama, masyarakat, orang tua, aparat desa, kementrian agama, dinas kesehatan untuk mencegah terjadinya pernikahan dini.

\section{Daftar Pustaka}

Al-Qur'an, kementerian Agama. 
Abdullah Nashin Ulwan, Mengapa Anda Belum Menikah Juga, Inilab Solusinya (Bandung: Dār al-Salam-Kairo, 2007).

Abu Al-Ghifari, Badai Rumah Tangga, (Bandung: Mujahid Press, 2003).

Bimo Walgito, Pengantar Psikologi Umum, (Yogyakarta: Penerbit Andi, 1989).

Creswell J, Research Desgin, dalam Ulber Silalahi, Metode Penelitian Sosial (Bandung:PT. Refika Aditama, 2010).

Eva Eliya Sibagariang, Kesehatan Reproduksi Wanita, Edisi Revisi, (Jakarta: Trans Info Media. 2016).

Henry S. Siswosudiro, Veronika Dian A, Mengurus Surat Kependudukan (Identitas Diri) (Jakarta: Visimedia, 2008).

Hilman Hadikusuma, Hukum Perkawinan Indonesia, (Bandung: Bandar Maju, 1990).

I Made Pidarta, Analisis Penelitian Kualitatif Konsep dan Contoh, (Surabaya: Universitas Negeri Surabaya,2004).

Kepala BKKBN Lotim H. Suroto kepada RADIO LOMBOK FM, Rabu 27/07/2016.

Lalu Makrifuddin, pada Rapat Koodinasi Daerah (Rakorda) BKKBN se NTB. Rapat ini berlangsung di Wisma Sumbawa, Lombok Pos.net, 23 Mei 2016.

Lombok Post, Koran Giri Menang: Lombok Barat Unggul, Mandiri, Sejabtera, dan Bermartabat Dilandasi Nilai Patut Patuh Patju (Senin, 25 Mei 2015)

Muhammad Kartono: Murtianingsih, Penyebab terjadinya Pernikahan Dini Pada Remaja di Pesisir Pantai Kuta Kabupaten Lombok Tengah, Jurnal Media Bina Ilmiah, ISSN No. 1978-3787, Vol. 8, No. 7 Desember 2014.

Penjelasan Undang-Undang No. 1 Tahun 1974 tentang Perkawinan.

Profil Sosial Ekonomi, Paritas, Status Dan Perilaku Kesehatan Pada Wanita Yang Menikah Dini Di Indonesia", Jurnal Kesehatan Reproduksi Vol. 4 No 2, Agustus (2013), hlm:51-60.

Sulistiyowati Irianto, Perempuan dan Hukum Menuju Hukum Yang Berpersepektif Kesetaraan dan Keadilan, (Jakarta: Yayasan Obor Indonesia). 2006.

Suprayogo dan Tobroni,Metodologi Penelitian Sosial Agama, (Bandung:PT. Remaja Rosdakarya, 2001).

Wulandari dan Sarwititi Sarwoprasodjo, "Pengaruh Status Ekonomi Keluarga 
Qawwãm • Volume 13 Nomor 1, Juni 2019

Terhadap Motif Menikah Dini di Perdesaan", Sodality : Jurnal Sosiologi Pedesaan | April (2014), hlm : 58.

Zuhdi Muhdlor, Memahami Hukum Perkawinan, (Bandung: al-Bayani, 1995). 